\title{
Anti-HER2 Antibody-drug Conjugate RC48
}

National Cancer Institute

\section{Source}

National Cancer Institute. Anti-HER2 Antibody-drug Conjugate RC48. NCI Thesaurus.

Code C130011.

An antibody-drug conjug ate (ADC) composed of a monoclonal antibody targeting human epidermal growth factor receptor 2 (EGFR2; HER2) and conjug ated to an as of yet undisclosed cytotoxic agent, with potential antineoplastic activity. Upon administration of anti-HER2 ADC RC48, the antibody moiety targets and binds to HER2 on tumor cells. Upon antibody/antigen binding and internalization, the cytotoxic agent induces tumor cell apoptosis, through an as of yet not publicly known mechanism. HER2, a tyrosine kinase receptor, is overexpressed by many cancer cell types. 